\title{
WYRAŻANIE MODALNOŚCI W JEZZYKU CHORWACKIM, SERBSKIM I POLSKIM. PODOBIEŃSTWA I RÓŻNICE LEKSYKALNYCH CZASOWNIKOWYCH WYKLADNIKÓW MODALNOŚCI
}

W wielu pracach semantycznych i pragmalingwistycznych pojeccie możliwości, często zestawiane $z$ pojęciem konieczności, rozpatrywane jest jako jedna $z$ kategorii modalnych.

Koncepcje modalności proponowane przez językoznawców w dużym stopniu przedstawiaja zastosowanie zbioru wyrażeń modalnych (formy trybu, czasowniki modalne, partykuły modalne typu: może, chyba itd.) [Holvoet 1989, 18].

Tematyka dotykajaca zagadnień modalności jest szeroka i nie sposób wyczerpująco omówić i odwołać się do wszystkich jej aspektów. W niniejszej pracy pragnę skoncentrować się jedynie na zastosowaniu czasownikowych wyrażeń modalnych w języku chorwackim, serbskim i polskim.

Uniwersalny słownik języka polskiego ${ }^{1}$ określa modalność jako 1. filoz. „w tradycyjnej ontologii charakterystykę stanów, rzeczy i zjawisk pod względem sposobu, w jaki one istnieja, zachodzą", log. modalność zdań w „tradycyjnej logice: charakterystyka zdań pod względem sposobu stwierdzania przez nie faktów, tj. pod względem stopnia kategoryczności (pewności), z jaka zdania coś orzekaja”. 2. jęz. „stosunek osoby mówiącej do tego, co jest treścia jej wypowiedzi, wyrażany głównie przez formy trybów czasownika, a także za pomoca partykuł, niektórych czasowników, utartych zwrotów, intonacji itp.". Hrvatski leksikon ${ }^{2}$ określa modalność jako:

modalitet (lat.), filoz. način bivanja, postojanja (ontološki m.) ili zamišljanja (gnoseološko-logički m.). Ontološki m.: stvarnost, mogućnost, nužnost, a logički m. (kao vrste sudova): problematički, asertorni i apodiktički.

1 Uniwersalny słownik języka polskiego pod red. nauk. S. Dubisza, t. 2, Wydawnictwo Naukowe PWN, Warszawa 2003.

2 https://www.hrleksikon.info/definicija/modalitet.html [dostęp: 11.12.2018]. 
Serbski Rečnik sinonima ${ }^{3}$ definiuje modalność jako: „misaoni, logički postupak, način izvršenja / ostvarivanja nečega".

Zajmując się tematyka modalności, należy jednak przede wszystkim przytoczyć koncepcję Johna Lyonsa [za: Holvoet 1989, 18,19], który wyróżnił trzy typy tego zjawiska:

- modalność aletyczna - dotycząca prawdziwości zdań, np. możliwe jest, $\dot{z} e$...

- modalność epistemiczna - wyrażająca ocenę prawdziwości zdań w świetle wiedzy mówiącego, formalnymi wykładnikami są funktory móc, musieć.

- modalność deontyczna - obejmująca takie znaczenia jak nakaz, zakaz, obowiąek, pozwolenie.

Niektórzy językoznawcy wprowadzaja również podział modalności subiektywnej, informującej o postawie nadawcy, i obiektywnej, informującej o konieczności lub możliwości zachodzenia zjawisk w świecie zewnętrznym [Grzegorczykowa 1990, 137]. Zdanie: Jan musi pójść na zebranie jest dwuznaczne. Zawiera bowiem informację o nadawcy, który uważa, że „jeżeli Jan nie pójdzie, będzie źle”. Nadawca postuluje, że zachodzi obiektywna konieczność pójścia Jana na zebranie, a nadawca jedynie stwierdza taki stan rzeczy. Zdanie: Jan musi pójść na zebranie w drugim rozumieniu wskazuje na stan konieczności, który nazywa się modalnością aletyczną [1990, 137].

Modalność jest nieodłącznie związana $z$ pojęciem mocy, możliwości. Według Anny Wierzbickiej moc jest synonimem siły [1971, 133], czyli $<$ moc (siłę) ma ten, kto dużo może>. Móc według Tomasza Wójcika [1975, 136] można rozumieć w znaczeniu <być w stanie>, <potrafić>. Wszystkie trzy wyrażenia: móc, być $w$ stanie, potrafić sa stosowane przez Andrzeja Otfinowskiego w parafrazie podołać [1976, 135, 136] [za: Chojnacka $1999,15]$. Wyrażanie oznaczające możliwość pojawia się również w parafrazach wyrażeń: przydatny do, dobry do, nadawać się do, podległy czemuś [Otfinowski 1976, 136, 142].

Modalność definiuje się często jako wyrażenie przez mówiącego stosunku między wypowiadanymi przez niego wyrażeniami zdaniowymi a treścią tych wyrażeń (sytuacja pozajęzykowa), a także stosunku mówiącego do treści wypowiadanego przez niego wyrażenia zdaniowego. Stosunek ten może polegać na stwierdzeniu bez zastrzeżeń opisywanej sytuacji, a także może nakładać pewne ograniczenia na prawdziwość wygłaszanego zdania, a więc wskazywać stopień obiektywnego prawdopodobieństwa prawdziwości zdania, wyrazić siłe przekonania nadawcy o prawdziwości zdania lub całkowicie odżegnać się od stwierdzenia prawdziwości zdania [Bojar, Korytkowska 1991, 40].

3 P. Ćosić i in., Rečnik sinonima, Beograd 2008. 
Pojęcie możliwości nie jest pojęciem jednoznacznym. Vjara Maldžieva podaje schemat opisu modalności językowej przedstawiający jej wielopłaszczyznowość. Ukazuje to następująca proporcja:

$\frac{\text { niewiedza nadawcy }}{\text { możliwość }}=\frac{\text { niepewność nadawcy }}{\text { możliwość }}=\frac{\text { wola nadawcy }}{\text { możliwość }}$

Pojęcie możliwości jest rozumiane jako wartość nadawana pewnym treściom przez nadawcę. Treść wynikająca ze stanu mentalnego nadawcy wchodzi w pewne stałe relacje $z$ innymi pojęciami, takimi jak: „prawdopodobieństwo, pewność, przekonanie, zależność, warunek, przyczyna, wola, konieczność, niemożliwość" [Maldžieva 2003, 130-131]. Zdaniami nacechowanymi modalnie sa te, które zawierają nadwyżkę w postaci nacechowania pod względem możliwości / konieczności. Wyrażenia odnoszace się do konieczności i możliwości, które nie są umotywowane kontekstowo, moga stanowić substytut wyrażenia typu: jest pewne dla konieczności oraz typu jest prawdopodobne dla możliwości, por. takie wykładniki językowe tych kategorii jak pol. na pewno, chor./serb. Sigurno / сигурно, bułg. Sigurno / sas sigurnost, pol. prawdopodobnie, chyba, chor./serb. vjerojatno, вероватно, moguće, могyћe, bułg. može bi, verojatno [Bojar, Korytkowska 1991, 41].

Bardzo ważnym elementem, który warto również przytoczyć, jest kwestia homonimii wyrażeń modalnych. Wprowadzenie wyrażenia móc / moći lub możliwe, że / moguće da zmienia właściwości pragmatyczne zdania. W zależności od kontekstu zdania oraz użycia kwantyfikatorów modalnych możemy interpretować intencję nadawcy.

Podstawowe dla opisu modalności sa pojęcia możliwości i prawdziwości i powinny one być rozumiane jako sposób, w którym język przedstawia dane sytuacje. Przedmiotem postawy modalnej nadawcy sa szeregi stanów i zdarzeń, przedstawionych $z$ punktu widzenia nadawcy.

Piszacc o modalności, pragnę skoncentrować się w głównej mierze na istocie czasowników modalnych. Wśród autorów nie ma jednolitego poglądu na to, które czasowniki można uznać za modalne. Ustalenie kryteriów wyróżnienia czasowników i predykatywów modalnych komplikuje się dodatkowo wobec faktu, że niektórym czasownikom modalnym, takim jak musieć, móc - można w różnych kontekstach przypisać interpretację semantyczna zarówno deontyczna, jak i epistemiczna i aletyczna, niektóre natomiast realizuja znaczenia modalne ograniczone do dwóch, np. deontycznego i epistemicznego (mieć, powinien), deontycznego i aletycznego (należy oraz predykatywy trzeba, można), czy tylko jednego, jak w wypadku deontycznego predykatywu wolno [Ligara 1997, 47].

Björn Hansen wyróżnia dwa typy czasowników modalnych, które można rozróżnić na podstawie ich semantycznych i morfosyntaktycznych właściwości [2007, 31]. Zaczynając od definicji czasowników modalnych jako 
wielofunkcyjnych środków wyrażania modalności [2007, 34], B. Hansen odróżnia czasowniki modalne mające ścisłe znaczenie fully-fledged modal auxiliaries), odpowiadające wyrażeniom: móc: moći; musieć: morati; potrzebować: trebati; valjati: mieć wartość, oraz czasowniki półmodalne tzw. polumodale (semi auxiliaries): hteti: chcieć, imati: mieć, smeti: móc [2007, 35].

Lejla Zejnilović podaje, iż czasowniki modalne morati (musieć), moći (móc), trebati (musieć), hteti (chcieć), smeti (móc), umeti (umieć), želeti (chcieć) moduluja znaczenie czasownika, z którym się łączą, tj. pokazuja, że dana sytuacja nie jest realistyczna, ale jest możliwa jako sytuacja, która wyrażona jest za pomoca leksemów: musieć, móc, chcieć. Innymi słowy, modalne czasowniki uczestniczą w tworzeniu złożonego predykatu, który pełni funkcję wyrażania osobistego stosunku podmiotu do tego, co stanowi cały orzecznik [Stevanović 1969, 598].

Poniższy opis będzie stanowić ilustrację pozwalająca ukazać zastosowanie czasowników modalnych w języku polskim, chorwackim i serbskim.

\section{CZASOWNIK MORATI (MUSIEĆ)}

Czasownik morati (musieć) określa się jako nośnik znaczenia epistemicznego i deontycznego [Piper 1983, 167]. Czasownikowi musieć przypisuje się znaczenie modalne:

I. a) obowiązku,

b) konieczności,

c) koniecznego chcenia;

oraz

II. silnego prawdopodobieństwa [Ligara 1997, 67].

Według Ewy Jędrzejko znaczenia podstawowych leksemów deontycznych musieć, powinien, móc, opierają się na założeniu, że modalność deontyczna odnosi się do świata obowiąkowych lub dozwolonych działań ludzkich. Obowiazek i pozwolenie to stany powodowane przez obdarzonego wola i autorytetem (władza) osobowego sprawcę (może nim być jednostka lub zbiorowość ludzka, także np. bóstwo). Zakłada się więc, że zawsze istnieje jakiś $\mathrm{X}$, który jest sprawca konieczności (lub możliwości) działania pewnego Y [1987, 35-39].

Konstrukcje $z$ czasownikiem deontycznym musieć mogą też mieć inna interpretację, w której negatywny skutek niewykonania czynności postulowanej nie jest spowodowany przez sprawcę obowiazku. Zdanie: Musisz założyć szalik, bo się przeziębisz informuje o istnieniu obowiąku, który nakłada na Y pewien niejasny X. Obowiazek ten wynika $z$ istnienia zewnętrznej (aletycznej) konieczności, określającej związek między postulowanym zdarzeniem a skutkiem jego niespełnienia [1987, 39]. 
Zakres znaczeniowy poszczególnych leksemów wyrażajacych konieczność deontyczną nie jest wyraźnie zarysowany. Dzieje się tak, ponieważ o wyborze wyrażenia modalnego w większym stopniu decyduja właściwości pragmatyczne dostępnych nadawcy środków leksykalnych niż ich właściwości semantyczne [Holvoet 1989, 129]. Konieczność deontyczna obejmuje cały szereg nieraz bardzo różnorodnych wyrażeń, których wspólną cecha jest to, że sa w pewnym stopniu oparte na wyrażeniach wolitywnych. Interpretowanie zdań, wyrażających konieczność deontyczna, rozpatrywanie ich w oderwaniu od kontekstu, jest zazwyczaj bardzo trudne [1989, 129]. Zdanie:

Muszę wyjechać

Moram otputovati

może oznaczać 1. zobowiąanie nadawcy do takiego działania; 2 . opinię nadawcy, że takie działanie jest wskazane w danej sytuacji; 3. możliwość zmuszenia nadawcy do takiego postępowania [1989, 129].

Predrag Piper uważa na przykład, że czasownik morati może się polaryzować w zależności od kontekstu zdania. Według badacza istnieje różnica między wyrażaniem stosunku nadawcy do wyrażenia i subiektywnej ramy, która wyraża się stosunek podmiotu do predykatu [Piper 1983, 168]. Ilustrują to następujące przykłady:

1. Mora uzeti lijek.

(Musi przyjać lek)

2. Mora uzimati lijek jer mu je liječnik tako rekao.

(Musi przyjmować lek, bo tak mu zalecit lekarz)

3. Mora uzimati lijek da bi ozdravio.

(Musi przyjmować lek, żeby wyzdrowieć)

Predrag Piper wyróżnia również dwie kategorie znaczenia czasownika morati: nieapodyktyczna i apodyktyczna (czyli perswazyjno-apodyktyczna).

Nieapodyktyczne perswazyjne znaczenie czasownika morati wyraża pewien stopień przekonania osoby mówiącej do treści zdania za pomoca możliwych substytucyjnych wyrażeń typu: sigurno, svakako, bez sumnje, vjerujem da. Przykładem może być zdanie: Naši ljudi moraju pobijediti (Nasi musza wygrać), ale możliwa jest też transformacja zdania:

Vjerujem da naši ljudi pobijede.

Apodyktyczne zastosowanie czasownika morati P. Piper przypisuje wyrażeniom, w których morati oznacza to samo, co sasvim sigurno znam (na pewno wiem, jestem przekonany). Sa to zatem wyrażenia niepodważalne, co do których nadawca ma pewność wynikająca z pewnej wiedzy ogólnej, np.: 
Voda mora da proključa na $100^{\circ} \mathrm{C}$, Sve što živi mora i da umre, (Woda wrze w temperaturze $100^{\circ} \mathrm{C}$, Wszystko, co żywe, umiera) [Piper 1983, 168-169].

Czasownik morati wiąże się przede wszystkim $z$ obligatoryjnymi aspektami znaczeniowymi i to zalicza go do domeny deontycznej modalności. P. Piper przedstawia również różnicę między bezpośrednią a pośrednią obligatoryjnościa czasownika morati. Bezpośrednie ekwiwalenty to zatem: biti primoran, biti natjeran, biti prisiljen (być zmuszonym), pośrednie: biti dužan, biti obavezan, biti neophodan, biti nužan.

Dušanka Zvekić-Dušanović, zajmująca się podziałem czasowników modalnych w języku serbskim, stwierdza, że serbskie czasowniki modalne sa rozpoznawane przez swoja semantyczna niekompletność, niesamodzielność składniowa, to znaczy czasownik obowiazkowo jest uzupełniony forma bezokolicznika lub w formie konstrukcji $d a+$ prezent [2011, 38-41].

Przykłady:

(serb.) Морам да идем.

(chor.) Moram ići.

(pol.) Muszę iść.

(serb.) Mopa да uде (on /ona).

(chor.) Mora ići (on /ona).

(pol.) Musi iść (on /ona).

Dušanka Zvekić-Dušanović klasyfikuje morati do grupy czasowników modalnych o znaczeniu epistemicznym, wyrażajacym wysoki stopień przekonania i prawdy [2010, 152-154].

Semantyczne interpretacje czasownika morati maja swoje zanurzenie w tzw. „motywach” [Zvekić Dušanović, tamże], dotyczącego pojęcia, które pokrywa znaczenia, które przypadają domenie deontycznej i dynamicznej modalności [2010, 146]. Semantyczna struktura modalności opartej na tzw. motywach może być postrzegana według autorki w sposób dwuwymiarowy, w których jeden wymiar wyrażać mógłby zachętę i możliwość, a drugi swoisty impuls działający na odbiorcę w celu osiagnięcia zamierzonego celu.

\section{CZASOWNIK MOĆI (MÓc) I WYRAŻENIA IMATI MOGUĆNOST (MIEĆ MOŻLIWOŚĆ)}

Czasownik moći jest czasownikiem modalnym, którego znaczenie moga określać leksemy: możliwość i pozwolenie, zdolność [Trbojević-Milośević 2004, 148), co pozwala na sklasyfikowanie czasownika moći w grupie modalności epistemicznej, deontycznej i dynamicznej. 
W świetle modalności epistemicznej czasownik moći wskazuje na średni stopień prawdopodobieństwa [Hansen 2007, 30]. Pod katem modalności deontycznej czasownik moći oznacza 'pozwolenie' lub jak pisze Zvekić-Dušanović [2010, 89], czasownik ten może również oznaczać swoistą 'możliwość zewnętrzną. W końcu patrząc $z$ perspektywy modalności dynamicznej, czasownik ten koduje znaczenie zdolności, umiejętności działania, robienia czegoś [Trbojević-Milošević 2004, 149].

Domena modalności dynamicznej, według D. Zvekić-Dušanović [2010, 70] wchodzi w skład tzw. <możliwości obiektywnej>, która nastaje wskutek zbiegu okoliczności (cirkumstancijalna mogućnost), na przykład w zdaniach:

1. Ujak je mogao da izjavi ljubav na četiri jezika.

2. Wujek mógł wyznać miłość w czterech językach.

(w języku polskim można również powiedzieć w tym wypadku zamiast mógt-potrafit, co w chorwackim mogłoby mieć odpowiednik znao je izraziti).

1. Ana je mogla govoriti i pisati u isto vreme.

2. Ana mogła mówić i pisać $w$ tym samym czasie.

Ivana Trbojević-Milošević [2004, 158] uważa, że w przeciwieństwie do angielskiego, w języku serbskim i chorwackim trudno rozróżnić typy modalności w zdaniach, w których moći zostało użyte w funkcji wyróżnika modalności, np.:

1. Najneviniji komentar mogu da shvate kao tešku kritiku.

2. Najbardziej niewinny komentarz moga odebrać, jako ciężka krytykę.

W świetle epistemicznej interpretacji czasownika moći autorka sugeruje również parafrazę zdania, posiłkując się takimi wyrażeniami jak:

Moje premise (i dostpuni dokazi) me ne sprečavaju da zaključim da najneviniji komentar mogu da shvate kao tešku kritiku. (Przyjęte przez mnie dowody nie przeszkadzaja mi w założeniu, że najbardziej niewinny komentarz moga odebrać jako ostra krytykę.)

Natomiast pod względem modalności deontycznej zdanie można parafrazować, posiłkując się wyrażeniami:

Sposobni su / imaju sposobnost da najneviniji komentar mogu da shvate kao tešku kritiku.

(Oni są w stanie, żeby najbardziej niewinny komentarz odebrać jako ostrą krytykę.)

Czasownik moći może być zatem wyrażony w języku serbskim i chorwackim poprzez leksemy: imati mogućnosti, imati sposobnost, biti sposoban. W języku polskim możliwość wyrażamy także za pomoca analogicznych wykładników: mieć możliwość, mieć okazję, mieć sposobność, lub też zanikającej już formy mieć możność. Możliwość jest również wy- 
rażana za pomoca leksemu szansa. W języku polskim mówi się mieć szansę na coś, w języku chorwackim i serbskim: imati priliku za nešto.

W potocznym odczuciu wyrażenia mieć okazję używamy wtedy, gdy mamy na myśli zewnętrzne sprzyjające czemuś, ułatwiające coś okoliczności, warunki. Może to przedstawić następujący schemat:

A sprzyja $B=A$ powoduje, że możliwość $B$ jest dla $X$-a większa.

Przykład: Jan ma możliwość / okazję wyjechać do Włoch [Chojnacka 1999, 70].

Wspomniane już wyrażenie mieć szansę chor./serb. imati priliku jest głównym elementem zdań odpowiadających schematom [Chojnacka 1999, 77]:

1. X ma szansę.

2. X ma szansę na Y.

3. X ma szansę, żeby ...

4. X ma szansę na...

5. X ma szansę w...

6. X ma szanse u...

7. X ma szanse, że...

1. X ima priliku.

2. X ima priliku za Y.

3. X ima priliku da....

4. $\mathrm{X}$ ima priliku $\operatorname{kod} Z$.

Można przypuszczać, że w eksplikacji szansy występuja składniki, które stanowią zawartość semantyczna prawdopodobieństwa. Ponieważ prawdopodobieństwo jest cechą sądów, które nie sa ani prawdziwe, ani fałszywe, lecz możliwe, zaproponować można następującą eksplikację wyrażenia coś jest prawdopodobne [1999, 77]:

coś jest prawdopodobne = ktoś sadzi, że to coś może być (stać się); że to coś jest możliwe.

Nadawca uznaje więc jakiśs stan rzeczy za prawdopodobny, ponieważ wskazują na to okoliczności oraz warunki, w których on występuje. Prawdopodobieństwo czegoś, o czym mówi nadawca, jest wynikiem wnioskowania [1999, 78].

\section{CZASOWNIK TREBATI (POTRZEBOWAĆ / MUSIEĆ)}

Czasownik trebati jest czasownikiem, który najtrudniej jest przełożyć na język polski. W znaczeniu dosłownym oznacza 'potrzebować', jednak w kontekście modalności wyraża on znaczenie odpowiadające polskiemu 
'musieć'. Trebati można również określić jako wyrażenie bliskoznaczne $z$ morati.

Trebati wyraża słabsze przekonanie, a właściwie przypuszczenie. W epistemicznym ujęciu jest ono bliższe móc niż musieć [Kryzia 2005, 100]. Wyizolowane $z$ kontekstu zdanie: Jan powinien być na wykładzie; chor. Jan treba biti na predavanju, może oznaczać, że nadawca sądzi, że 'Jan ma obowiązek być na wykładzie, bo ktoś mu kazał lub sam komuś obiecał' albo że 'dobrze by było, gdyby Jan był na wykładzie (ze względu na korzyść $z$ tego wynikająca), lub też nadawca wyraża swoje przypuszczenie (stopień przekonania), że 'Jan jest na wykładzie' [2005, 100].

Czasownik trebati często określa się jako majacy najsłabsza moc deontyczną i epistemiczną [Zejnilović 2017, 106]. Mówi się, że ten czasownik należy do kategorii deontycznej w znaczeniu konieczności, przy czym konieczność, która wyraża czasownik trebati, określana jest jako „słabsza konieczność" [Piper 2005b, 640].

Według Snježany Kordić [2002, 186] trebati to osłabiony rozkaz, polecenie. Czasownik trebati zalicza się do kategorii słabej epistemicznej modalności, która i tak jest silniejsza od modalności wyrażonej czasownikiem moći, ale jest $\mathrm{w}$ dalszym ciagu słabsza od czasownika morati [Trbojević-Milošević 2004, 161].

\section{MORATI \\ 2. TREBATI \\ 3. MOĆI}

W czasowniku trebati mieści się także znaczenie 'obvezivati', czyli 'obowiąywać'. W tym wypadku czasownik trebati można postrzegać jako równoważny czasownikowi modalnemu morati, ale majacy nawet większą moc epistemiczną niż on [Trbojević-Milošević 2004, 161].

1. To treba biti njegova žena.

(To powinna być (najprawdopodobniej jest) jego żona).

2. To mora biti njegova žena.

(To musi być jego żona).

Jak twierdzi Ivana Trbojević-Milošević: „przymus nie pozostawia nam wyboru, ale obowiązu możemy, ale też nie musimy przestrzegać" [2004, 163].

W wypadku czasownika trebati wskazuje się na związek między bezosobowym użyciem i jego epistemicznym znaczeniem, jak również na bezosobowe użycie tego czasownika, kiedy wyraża się nim znaczenie deontyczne [Piper 2005b, 640]. Wyjątek stanowia przypadki, w których czasownik trebati, $z$ następująca po nim konstrukcją da (w wypadku języka serbskiego), użyty jest w czasie przeszłym lub w trybie przypuszczającym. W takim wypadku Predrag Piper zwraca uwagę na możliwość 
użycia w zdaniu zarówno osobowej formy czasownika, jak i bezosobowej formy czasownika. Ta ostatnia musi jednak zostać użyta tylko i wyłącznie na początku zdania.

Przykłady:

1. On je trebao da počne.

2. On miał zaczać.

3. On bi trebao da počne.

4. On powinien by zaczać.

5. Trebalo je da on počne.

6. Powinien był zaczać.

7. Trebalo bi da on počne.

8. Powinien by zaczać.

P. Piper wskazuje także możliwość użycia osobowej i bezosobowej formy czasownika trebati, jeżeli dopełnienie czasownika występuje w formie bezokolicznika, np.:

1. Treba početi.

2. Trzeba zaczać.

3. Treba ići.

4. Trzeba iść.

W powyższych wypadkach następuje nałożenie się znaczeniowe serbskiego, chorwackiego i polskiego czasownika modalnego trebati w znaczeniu 'trzeba', jednak rozbieżność występuje już w momencie użycia trebati w formie osobowej w wypadku języka serbskiego i chorwackiego. W takich sytuacjach trebati w języku polskim będzie znaczyć ponownie 'musieć', np. w zdaniach:

1. Trebaš ići.

2. Musisz iść.

3. Trebam spavati.

4. Muszę spać.

W języku polskim czasownik wyrażający powinność, obowiązek odzwierciedla się w zdaniach typu: Trzeba pomagać słabszym; Nie wolno deptać trawników [Grzegorczykowa 1990, 150]. Sa to wypowiedzi postulatywne, szczególnie widoczne w strukturze zakazów i nakazów ogólnych, w których ważniejsze od oceny jest zalecenie realizacji komunikowanego stanu rzeczy [1990, 151]. Informacje aksjologiczne zawarte w zdaniach $z$ modalnością deontyczną są zróżnicowane. Stanowią one kombinację ocen (źle, dobrze), negocjacji oraz elementu wolitywnego (presji nadawcy lub innych osób) [1990, 151]. W polszczyźnie zdania $z$ predykatem powinien, powinno się zawsze wyrażaja stanowisko nadawcy, natomiast 
zdania $z$ trzeba, wolno, nie wolno moga wyrażać zarówno przekonania nadawcy, jak i referowane przez niego cudze stanowisko, np. W Polsce trzeba meldować cudzoziemców (jest taki obowiazek); W stanie wojennym nie wolno było przebywać na ulicach po godzinie policyjnej. Wyrażenie powinno się sugeruje akceptację zalecenia przez nadawcę [1990, 151].

Według Ewy Jędrzejko pojęcie powinności należy traktować jako element $z$ tej samej przestrzeni semantycznej, co pojęcie obowiązku, a rozróżnienie leksemu musieć i powinien jest raczej kwestia pragmatyki niż semantyki. W języku naturalnym zarówno jeden, jak i drugi czasownik może określać obowiązek prawny lub moralny (por. konstrukcje: obowiązek rodzicielski, powinności płatnicze itp.) [Jędrzejko 1987, 43].

\section{CZASOWNIK SMETI, SMJETI (MÓC)}

Czasownik modalny smeti (serb.), smjeti (chor.) jest czasownikiem oznaczającym 'pozwolenie', 'nakaz', 'zakaz'. Hrvatski jezični portal tak definiuje czasownik smjeti: ${ }^{4}$

1. Imati dopuštenje da se što učini [smijem večeras u kino].

2. Imati smjelost što učiniti; usuditi se.

(1. Mieć pozwolenie na wykonanie czegoś [Mogę iść wieczorem do kina.]

2. Mieć odwage coś zrobić, odważyć się).

Czasownik smeti, smjeti może występować w zdaniach:

1. Smijem li otvoriti ovu bocu?

(Czy moge otworzyć te butelkę? / Czy wolno mi otworzyć tę butelkę?)

2. Ne smijem ti to reći jer sam joj to obećala.

(Nie moge ci tego powiedzieć, bo jej to obiecałam / Nie wolno mi tego powiedzieć, bo jej to obiecałam).

Czasownik smjeti można określić jako deontyczny, wyrażający śmiałość lub ośmielenie nadawcy do wykonania danego działania. $Z$ drugiej strony smjeti można postrzegać także $z$ perspektywy modalności epistemicznej, kiedy czasownik ten jest użyty w przeczeniu lub w trybie przypuszczającym. Przykładem może być zdanie:

1. To ne smije biti ona.

(To nie może być ona.)

2. To ne bi smijela biti ona.

(To nie mogłaby być ona.)

4 http://hjp.znanje.hr/index.php?show=search_by_id\&id=d111UBc\%3D [dostęp: 11.12.2018]. 
Polskim ekwiwalentem czasownika smjeti / smeti jest czasownik: móc, wolno. Według Bronisławy Ligary predykatowi wolno można przypisać taką samą eksplikację jak dla móc. Jest to parafraza: „X pozwala Y-owi zrobić P". Struktura semantyczna wolno nie różni się zasadniczo od semantyzmu móc (deon.), natomiast sama postać leksykalna predykatywu wolno silniej i dobitniej presuponuje składnik jego struktury semantycznej, jakim jest ukazanie potencjalnego zakazu, niż to ma miejsce z czasownikiem polisemicznym móc [Ligara 1997, 243].

\section{CZASOWNIK HTJETI (HTETI), UMETI (ZNATI) (CHCIEĆ, MÓC)}

Czasownik htjeti wyrażający przede wszystkim wolę i chęć, pozwala na klasyfikację tego czasownika do modalności deontycznej [Hansen 2007, 40]. Jednakże Ivana Trbojević-Milošević [2004, 170] stwierdza, że można również mówić o epistemicznym odcieniu tego czasownika, kiedy jest on wykorzystywany w znaczeniu słowa: moći (móc). Podaje tutaj przykład następujacego zdania:

Ta infekcija hoće / može se pogoršati u vlažnim uslovima.

(Ta infekcja może się pogorszyć w wilgotnych warunkach.)

Ta infekcija hoće / ume da se pogorša u vlažnim uslovima.

Czasownik umeti w wyżej wymienionym kontekście występować może wyłącznie w języku serbskim. Język chorwacki, w podobnych zdaniach, będzie operował czasownikiem moći, htjeti, lub znati. Wówczas zdanie to może brzmieć:

Ta infekcija može se pogoršati u vlažnim uvjetima.

Ta infekcija hoće se pogoršati u vlažnim uvjetima.

Ta infekcija zna se pogoršati u vlažnim uvjetima.

W języku polskim konstrukcje chce się + infinitivus wyrażają stany fizyczne lub duchowe [Kryzia 2005, 25]. W języku chorwackim i serbskim, a także macedońskim, dla wyrażenia potrzeb fizjologicznych, a także (niekoniecznie) umotywowanej woli (chęci), rozpowszechniła się innego rodzaju konstrukcja, składajaca się $z$ formy 3. osoby liczby pojedynczej czasownika nazywającego czynność lub stan podlegający potrzebie, datiwu rzeczownika lub zaimka osobowego reprezentującego obiekt podlegający stanowi i partykuły se, por. chor. i serb. pije mi se 'chce mi się pić', jede mi se 'chce mi się jeść', a także nama se ide kući 'chcemy iść do domu', ne ide mi se u bioskop 'nie chce mi się iść do kina' [Kryzia 2005, 27].

Oprócz wyżej wymienionych czasowników do czasowników modalnych moga również sporadycznie należeć czasowniki: želeti (chcieć, pragnać), voleti (chcieć), valjati (nadawać się, odpowiadać) i imati (mieć) [Trbojević-Milošević 2014, 171]. 


\section{ZAKOŃCZENIE}

Konstrukcje modalne używane są często w codziennej komunikacji, szczególnie w sytuacjach, gdy nadawca stara się uniknać podejrzenia o narzucanie odbiorcy swojej woli, daje się to eksplikować następująco: „Nie narzucam swojej woli, zrobisz, jak uważasz, ale chcę dla ciebie jak najlepiej" [Komorowska 2008, 142].

Analizując język przez pryzmat modalności, możemy określić, w jaki sposób jego użytkownicy posiłkują się danymi leksykalnymi wykładnikami, jak wyrażaja i rozumieja pojęcie możliwości na tle wybranych języków słowiańskich (polski, chorwacki, serbski). Praca prezentuje użycia i znaczenia chorwackich i serbskich leksemów czasownikowych: musieć, móc, mieć możliwość, chcieć oraz ich polskich odpowiedników.

Język polski, chorwacki i serbski ze względu na przynależność do tej samej grupy językowej stanowią wdzięczne pole do analizy, dostarczając przykładów tożsamych albo wręcz przeciwnie, całkowicie odmiennych semantycznie i formalnie. Identyfikacja przedstawionych jednostek leksykalnych, nierzadko wchodzacych $\mathrm{w}$ pewne stałe relacje $z$ innymi leksemami, pozwala zobrazować możliwość jako wartość nadana przez nadawcę, jako sposób wyrażania postawy i jego punktu widzenia.

\section{Bibliografia}

A. Bogusławski, 2003, Może i być może [w:] J. Linde-Usiekniewicz, R. Huszcza (red.), Prace językoznawcze dedykowane Profesor Jadwidze Sambor, Warszawa, s. 11-43.

B. Bojar, M. Korytkowska, 1991, Problemy modelowania kategorii modalności a wykładniki leksykalne tej kategorii [w:] V. Koseska-Toszewa, M. Korytkowska (red.), Studia gramatyczne bułgarsko-polskie, t. IV: Przewodnik po akademickiej gramatyce konfrontatywnej bułgarsko-polskiej: Modalność a inne kategorie jezykowe, Warszawa, s. 39-52.

S. Chojnacka, 1999, Możliwość a warunek (analiza znaczeniowa wybranych środków leksykalnych w języku polskim i rosyjskim), Bydgoszcz.

P. Ćosić (red.), 2008, Rečnik sinonima, Beograd.

S. Dubisz (red. nauk.), 2003, Uniwersalny słownik języka polskiego, t. 2, Warszawa.

R. Grzegorczykowa, 1990, Wprowadzenie do semantyki językoznawczej, Warszawa.

B. Hansen, 2001, Das slawische Modalauxiliar. Semantik und Gramamatikalisierung im Russichen, Polnischen, Serbischen / Kroatischen und Altikirschenslawischen, Munchen.

B. Hansen, 2007, A morpho-syntactic typology of constructions with modals in Serbian, „Sintaktička istraživanja (Diaxrono-Sinxroni Plan)”, Novi Sad, s. 31-44.

A. Holvoet, 1989, Aspekt a modalność w języku polskim na tle ogólnosłowiańskim, Wrocław-Warszawa-Kraków-Gdańsk-Łódź. 
E. Komorowska, 2008, Pragmatyka dyrektywnych aktów mowy w języku niemieckim, polskim i rosyjskim, Szczecin-Rostok.

S. Kordić, 2002, Riječi na granici punoznačnosti, Zagreb.

V. Koseska-Toszewa, I. Sawicka, J. Mindak (red.), 1986, Studia gramatyczne bułgarsko-polskie, t. I: Temporalność, Wrocław-Warszawa-Kraków-Gdańsk-Łódź.

V. Koseska-Toszewa, M. Korytkowska (red.), 1991, Studia gramatyczne bułgarsko-polskie, t. IV: Przewodnik po akademickiej gramatyce konfrontatywnej bułgarsko-polskiej, Modalność a inne kategorie językowe, Warszawa.

V. Koseska-Toszewa, M. Korytkowska (red.), 1993, Studia gramatyczne bułgarsko-polskie, t. V-VI: Konfrontacja językowa. Słowotwórstwo. Wybrane kategorie semantyczne, Warszawa.

V. Koseska-Toszewa, J. Baltowa (red. nauk.), 2003, Studia gramatyczne bułgarsko-polskie, t. VII: Przewodnik po akademickiej gramatyce konfrontatywnej bułgarsko-polskiej, Warszawa.

W. Kryzia, 2005, Polskie i słoweńskie predykaty modalne o znaczeniu 'chcieć', 'móc', 'musieć', 'powinien' na poszerzonym tle słowiańskim, Katowice.

B. Ligara, 1997, Polskie czasowniki modalne i ich francuskie ekwiwalenty tłumaczeniowe, Kraków.

V. Maldžieva, 2003 [w:] V. Koseska-Toszewa, J. Baltowa (red. nauk.), Studia gramatyczne bułgarsko-polskie, t. VII: Przewodnik po akademickiej gramatyce konfrontatywnej bułgarsko-polskiej, Warszawa.STRONY

J. Mindak, 1991, Admirativus w gramatycznej konfrontacji polsko-bułgarskiej [w:] V. Koseska-Toszewa, M. Korytkowska (red.), Studia gramatyczne bułgarsko-polskie, t. IV: Przewodnik po akademickiej gramatyce konfrontatywnej bułgarsko-polskiej: Modalność a inne kategorie językowe, Warszawa, s. 53-59.

A. Otfinowski, 1976, Konstrukcje orzeczeniowe z transforma gerundialna bez przyimka i z przyimkami, Bydgoszcz.

P. Piper, 1983, Sinonimije i konverzije s glagolom morati, „Naučni sastanak slavista u Vukove dane 12/1", Beograd, s. 167-172.

P. Piper, 2005, Sintaksa savremenoga srpskog jezika, Beograd.

M. Stevanović, 1969, Savremeni srpskohrvatski jezik (sintaksa), Beograd.

M. Szymczak (red.), 1979, Słownik języka polskiego, Warszawa.

I. Trbojević-Milošević, 2004, Modalnost, sud, iskaz: epistemička modalnost u engleskom i srpskom jeziku, Beograd.

A. Wierzbicka, 1971, Kocha, lubi, szanuje. Medytacje semantyczne, Warszawa.

T. Wójcik, 1975, Gramatyka języka rosyjskiego. Studium kontrastywne, Warszawa.

L. Zejnilović, 2017: Leksikalizovani i gramatikalizovani eksponenti modalnosti u pravnom diskursu engleskog i srpskog jezika, doktorska disertacija, Univerzitet u Beogradu, Filološki fakultet, Beograd.

D. Zvekić-Dušanović, 2010, O predikatima tipa treba hteti, treba smeti [w:] „Zbornik matice srpske za filologiju i lingvistiku" 53/1, Novi Sad, s. 143-162.

D. Zvekić-Dušanović, 2011, Modalnost: Motivaciona modalnost u srpskom i mađarskom jeziku, Novi Sad.

\section{Netografia}

https://www.hrleksikon.info/definicija/modalitet.html [dostęp: 11.12.2018]. 


\section{Expressing modality in the Croatian, Serbian, and Polish languages. Similarities and differences between lexical verbal exponents of modality}

\section{Summary}

This paper describes the similarities and differences between the lexical verbal exponents of modality in the Croatian, Serbian, and Polish languages. This study demonstrates the usages and meanings of the Croatian, Serbian, and Polish verbal lexemes: musieć (must / have to), móc (can/may), mieć możliwość (be able to), chcieć (want), and presents their classification from the angle of alethic, epistemic, and deontic modality.

Keywords: modality - alethic/epistemic/deontic modality - modal structure lexical exponents of modality - Croatian language - Serbian language

Trans. Monika Czarnecka 